\title{
Study of the Evolution of Cultivated Peanut through Crossability Studies among Arachis ipaënsis, A. duranensis, and A. hypogaea
}

\author{
Alessandra P. Fávero, Charles E. Simpson,* José F. M. Valls, and Natal A. Vello
}

\begin{abstract}
Genus Arachis L. includes 80 described species, of which 31 belong to section Arachis, including the two diploid species A. ipaënsis Krapov. and W.C. Gregory and A. duranensis Krapov. and W.C. Gregory, considered the putative $B$ and $A$ genome parents of the cultivated peanut. This work contributes to the study of evolution of the peanut (Arachis hypogaea $L$.), based on the successful hybridization between $A$. ipaënsis and $A$. duranensis, chromosome doubling of the hybrid, and crosses between the synthetic amphidiploid and representatives of the diversity of the crop. Diploid hybrids between A. ipaënsis and A. duranensis, confirmed by molecular markers, had pollen stains of $0.98 \%$. Colchicineinduced tetraploids were confirmed by mitotic chromosome counts. Progeny from these amphidiploid plants had a $97.74 \%$ pollen stain and significant differences among structure sizes measured in diploid and tetraploid flowers. Hybrid individuals [A. hypogaea $\times(A$. ipaënsis $\times$ A. duranensis $)^{4 x}$ ] were produced from crosses involving all six botanical varieties of $A$. hypogaea. These hybrids indicate the evolutionary similarity between the wild species and the cultigen. The successful hybridization between diploid species $A$. ipaënsis and $A$. duranensis and between $A$. hypogaea and the synthetic amphidiploid support the theory that these two diploids are the parents of the cultivated peanut. Resulting materials are of great importance to peanut breeding.
\end{abstract}

$\mathrm{T}$ He Genus Arachis includes 80 species (Valls and Simpson, 1994), 69 described by Krapovickas and Gregory (1994) and 11 described by Valls and Simpson (2005), 31 of which belong to the section Arachis. In this section, diploid species have annual or perennial behavior and show variable degrees of affinity to the complementary genomes that compose A. hypogaea and A. monticola Krapov and Rigoni, the two tetraploid species of the section. Husted $(1933,1936)$ observed the presence of two quite distinct chromosome pairs in the cultivated peanut: a pair he called A, with different staining behavior and much smaller than the remaining chromosomes, and another pair, with a secondary constriction, he called B. In spite of the observation by Husted (1936) and Smartt et al. (1978) of occasional meiotic tetravalents, the predominant bivalent pairing pattern of the chromosomes indicates the allotetraploid (or segmental allotetraploid) nature of $A$. hypogaea (Gregory and Gregory, 1976).

Alessandra P. Fávero and José F. M. Valls, Embrapa Genetic Resources and Biotechnology, SAIN Parque Estação Biológica, CP 02372, 70.770-900, Brasília, DF, Brazil; Charles E. Simpson, Texas Agric. Exp. Stn., Texas A\&M University, 1229 U.S. Hwy. 281 North, Stephenville, TX 76401-0004; Natal A. Vello, Department of Genetics, Escola Superior de Agricultura "Luiz de Queiroz", ESALQ/USP, C.P. 9, 13418-900, Piracicaba, SP, Brazil. J.F.M.V. received a CNPq Fellowship. Received 17 Oct. 2005. *Corresponding author (c-simpson@ tamu.edu).

Published in Crop Sci. 46:1546-1552 (2006).

Plant Genetic Resources

doi:10.2135/cropsci2005.09-0331

(C) Crop Science Society of America

677 S. Segoe Rd., Madison, WI 53711 USA
Gregory and Gregory (1976) proposed that the peanut could have developed through the crossing between an annual and a perennial species, both of the section Arachis. They suggested that detailed karyotype studies followed by experimental interspecific crossings should be made for parental identification. Re-creation of A. monticola or A. hypogaea was considered by them a real possibility of considerable interest. Smartt et al. (1978) suggested that $A$. hypogaea probably developed from the hybridization of two diploid wild species with different genomes.

The perennial species of the section Arachis have 20 chromosomes, including Husted's A pair and show more similarity and better crossability to each other than those that do not have the A pair, generally being classified as the A genome species (Stalker, 1989; Stalker et al., 1991). The same applies to the annual $A$. duranensis and A. stenosperma Krapov. and W.C. Gregory. Section Arachis species without the small pair are all annual and much more heterogeneous, including a group of three with $2 n=18$ chromosomes (Lavia, 1998; Peñaloza and Valls, 1997), one with six subtelocentric pairs (Fernández and Krapovickas, 1994), considered quite distant from $A$. hypogaea and classified by Stalker (1991) as a D genome species, and a third still heterogeneous group, with 20 metacentric or submetacentric chromosomes (or a rare subtelocentric pair), which includes the most probable non-A progenitor of $A$. hypogaea, A. ipaënsis (Fernández and Krapovickas, 1994). Since 1976, collection has accumulated species and germplasm accessions of section Arachis that cross with the peanut and are not associated to the A genome. Attempts of producing artificial AABB hybrids including $A$. ipaënsis, apparently the closest species to $A$. hypogaea on the basis of the karyotype and molecular markers, have consistently failed (Singh and Smartt, 1998). On the other hand, there is growing evidence of strong similarity between $A$. ipaënsis and A. magna Krapov, W.C. Gregory and C.E. Simpson (Simpson et al., 2001), and other species, such as A. williamsii Krapov. and W.C. Gregory, can also be included in this alliance, which increases the number of accessions available with the possibility of sharing the same B genome of the cultivated peanut.

Gregory and Gregory (1976) initially suggested $A$. duranensis and A. cardenasii Krapov. and W.C. Gregory as possible parents of the cultivated peanut. Based on cytological characterization and crossability studies, Smartt et al. (1978) suggested that several wild species of Arachis with A chromosomes could be potential donors of the A genome, $A$. cardenasii being the main candidate, while A. batizocoi Krapov. and W.C. Gregory was considered the possible donor of the B genome. For a long time, A. batizocoi had been the only species of section Arachis with available germplasm, that produced hybrids 
with A. hypogaea, but did not show the small A chromosome pair. In line with that, Gregory et al. (1980) warned that new collections were being made, so that other species could arise as possible progenitor candidates of A. hypogaea.

Based on seed protein data, Krishna and Mitra (1988) supported the indication of $A$. batizoco $i$ and $A$. duranensis or $A$. cardenasii being the progenitors of $A$. hypogaea. Singh (1986) suggested that the parents were $A$. duranensis and A. batizocoi, but in 1988 he accepted the possibility of biphyletic origin, suggesting that $A$. hypogaea subsp. fastigiata Waldron evolved from a diploid species such as $A$. batizocoi and $A$. duranensis while $A$. hypogaea subsp. hypogaea evolved from diploid species such as $A$. batizocoi and $A$. villosa Benth. Hybrids between $A$. hypogaea and amphidiploids involving $A$. batizocoi and A. duranensis showed high pollen fertility and good fruit production, as well as a high association in bivalents, however, meiosis was not totally normal.

Contradicting the above information, Stalker and Dalmacio (1986) discarded the hypothesis that A. cardenasii and $A$. batizocoi could be the ancestors, based on cytological characteristics. Hilu and Stalker (1995), based on RAPD markers, stated that $A$. duranensis is likely the donor of the $\mathrm{A}$ genome of $A$. hypogaea but also discounted $A$. batizocoi as the donor of the $\mathrm{B}$ genome. Later on, Singh et al. (2002), stated that A. batizocoi could not be a parent of $A$. hypogaea, based on the relationship of repetitive ribosomal DNA polymorphism units of 77 accessions of wild species and $A$. hypogaea.

Kochert et al. (1991) using RFLP markers, suggested that the parents of $A$. hypogaea are A. ipaënsis and $A$. duranensis. Krapovickas and Gregory (1994), Fernández and Krapovickas (1994), and Seijo et al. (2004) also support this possibility. Fernández and Krapovickas (1994) demonstrate that the so-called B chromosome pair is present in every diploid Arachis species, including those also showing the small A pair. Therefore, the presence alone of a chromosome with a secondary constriction in a section Arachis species will not automatically qualify such species as a potential B genome donor. Fernández and Krapovickas (1994) suggest that the presence of a single pair with a secondary constriction in A. hypogaea is a consequence of the amphiplastic inhibition of one of such pairs brought in by both diploid parent species. Kochert et al. (1996) considered that $A$. duranensis was the female parent of the original hybridization event, while stressing a large amount of RFLP variability was found among the accessions of $A$. duranensis. Accessions they considered the most similar to the A genome of $A$. hypogaea were identified as accessions mostly concentrated in the Salta Province of Argentina.

Paik-Ro et al. (1992), using RFLP markers in 14 accessions of $A$. hypogaea, seven of $A$. monticola, four of $A$. batizocoi, four of $A$. cardenasii, five of $A$. duranensis, and four of $A$. glandulifera, suggested that $A$. duranensis is the closest diploid species to $A$. hypogaea, mainly the accession PI 468201 (also from Salta), that had similarity in more than 11 RFLP probes from a total of 13 probes. However, A. ipaënsis was not considered in the analysis. A closer affinity of $A$. ipaënsis than that of $A$. duranensis to the A. hypogaea/A. monticola accessions or introgression lines has been documented by Gimenes et al. (2002), using AFLP and RFLP markers. Most probably, each of the two species is showing its closest relationship to a different genome of the tetraploid $A$. hypogaea, and there is an appreciable agreement in the literature as concerns their complementary importance to the origin of the cultivated peanut.

Krapovickas and Gregory (1994) state that A. monticola, a wild tetraploid species that crosses with $A$. hypogaea, generating fertile descendents, could be a parent of the cultivated peanut or a derivative. However, they believe that the most likely parental species of $A$. hypogaea would be $A$. ipaënsis and $A$. duranensis, and they do not discard the possibility of a polyphyletic origin. A possible area for the origin of the peanut would be in the southeast of Bolivia and northwest of Argentina, where natural populations of $A$. ipaënsis, A. duranensis, A. batizocoi, and A. monticola could come together, corroborating the hypothesis that two wild sympatric species, carrying the $\mathrm{A}$ and $\mathrm{B}$ genomes, were crossed by bee pollination, generating a sterile hybrid that would be naturally chromosome doubled. Those fertile hybrids would have been domesticated by the native people of the area.

Later on, using RAPD and ISSR markers in a study of genetic diversity, Raina et al. (2001) observed that A. villosa, A. ipaënsis, $A$. monticola, and $A$. hypogaea form a group in the dendrogram, while $A$. duranensis formed a distinct group with $A$. cardenasii. Raina and Mukai (1999a, 1999b) considered A. ipaënsis and $A$. villosa Benth. to be the most probable progenitors of A. hypogaea, based on the observation of $18 \mathrm{~S}-5,8 \mathrm{~S}-26 \mathrm{~S}$, and 5S ribosomal loci for fluorescent in situ hybridization (FISH) and for genomic in situ hybridization (GISH). It is remarkable that their findings would discard the possibility of $A$. duranensis being one of the parents of the cultivated peanut. However, a more comprehensive FISH study by Seijo et al. (2004) reestablishes $A$. duranensis as the most probable donor of the A genome, although A. villosa is only discarded on geographic and morphological grounds.

Stalker et al. (1991) tried to hybridize A. ipaënsis and A. hypogaea, without success. Singh and Smartt (1998) took this as an indication that perhaps $A$. ipaënsis would not be the donor of the $\mathrm{B}$ genome of $A$. hypogaea. They suggest that one should apply more probes to enhance the covering of the genome before defending this hypothesis.

Singh and Smartt (1998) suggested that until a fertile synthetic amphidiploid is produced between $A$. duranensis and $A$. ipaënsis and it is crossed with $A$. hypogaea to produce a fertile hybrid, hypotheses on the probable parents of $A$. hypogaea would not be confirmed. They suggested that $A$. batizocoi would continue being the probable donor of the $\mathrm{B}$ genome, because of the cytogenetic similarity with $A$. hypogaea and stated that the re-creation of $A$. hypogaea could not be made in an exact way, due to the long time between the present and the origin of the species. It is important to note the proven usefulness of $A$. batizocoi in breeding programs, as a component of amphidiploids that produce fertile hybrids with A. hypogaea, 
therefore allowing the introgression of resistance genes from wild relatives into the cultigen (Simpson and Starr, 2001). The status of $A$. batizocoi as a putative progenitor of $A$. hypogaea is denied by the results obtained by Seijo et al. (2004), based on the physical mapping of the $5 \mathrm{~S}$ and 18S-25S rRNA genes by FISH.

The objective of the present work is to report the crossability between A. ipaënsis and A. duranensis, and the accomplishment of tetraploidization through colchicine use, followed by successful crosses of the synthetic amphidiploid with several accessions of A. hypogaea. This work was conducted to study the evolution of the cultivated peanut through interspecific crossings, assuming the principal candidates to parents of $A$. hypogaea to be A. ipaënsis and A. duranensis.

\section{MATERIALS AND METHODS}

The experiment was conducted at the Department of Genetics of the School of Agriculture Luiz de Queiroz, ESALQ/ USP, Piracicaba, São Paulo State, and at Embrapa Genetic Resources and Biotechnology, Brasilia, Federal District, Brazil. Accessions involved are shown in Table 1 and were supplied by Embrapa Genetic Resources and Biotechnology and by the Agronomic Institute of Campinas (IAC), São Paulo State, Brazil.

\section{Crosses}

From April 2000 to June 2001, crosses were made between species of section Arachis considered to have distinct genomes. An accession of $A$. duranensis (A genome) from the city of Salta, Argentina, was used as male parent and the only available accession of A. ipaënsis (B or non-A genome) as female parent (Table 1).

The hybridization technique consisted of emasculation of flowers of the female parents in bud phase between 1600 and $1900 \mathrm{~h}$. In the morning of the following day, emasculated flowers were pollinated from 0700 to $0800 \mathrm{~h}$, using pollen of the male parent.

Between August and October 2001, hybrids were identified by molecular analysis. Microsatellite marker technique was used for the separation of hybrid and possible self-pollinated individuals. This technique was chosen due to its codominant nature, easiness, and speed in providing results.

\section{Molecular Characterization of the Hybrid between A. ipaënsis and A. duranensis}

Leaves of each plant of the progeny were collected individually and DNA was extracted from leaves according to the adapted protocol of Murray and Thompson (1980). This stage of the research was done in the Laboratory of Plant Cellular and Molecular Biology of the Department of Genetics of the Faculty of Agriculture Luiz de Queiroz, ESALQ/USP. The amount of DNA was quantified by the use of agarose gels $(1.2 \%)$ with $80 \mathrm{~V}$ for $1 \mathrm{~h}$ and diluted to the new concentration (2.5 $\left.\mathrm{ng} \mathrm{mL}^{-1}\right)$. DNA amplification reaction (polymerase chain reaction [PCR]) had a final volume of $13 \mathrm{~mL}$, and the reagents were mixed in the cocktail form, separately from DNA. Each reaction contained PCR buffer $(10 \mathrm{~m} M$ Tris- $\mathrm{HCl} \mathrm{pH} 8.3$ and $50 \mathrm{~m} M \mathrm{KCl}$ ), $1.5 \mathrm{~m} M \mathrm{MgCl}_{2}, 2.5 \mathrm{~m} M$ dNTPs, 5 pmol primers pair, $5 \mathrm{U} \mathrm{mL}^{-1}$ Taq DNA polymerase, $10 \mathrm{mg} \mathrm{mL}^{-1}$ BSA (bovine serum albumine), and $2.5 \mathrm{ng} \mathrm{mL}{ }^{-1}$ DNA. Sterile Milli-Q water was added to complete the volume to $13 \mathrm{~mL}$ in the reaction. Mineral oil (50 mL) was applied to avoid evaporation of the cocktail. The PCR program consisted of the reaction: (i) $5 \mathrm{~min}$ at $94^{\circ} \mathrm{C}$; (ii) 29 cycles with three stages $\left(1 \mathrm{~min}\right.$ at $94^{\circ} \mathrm{C}$, $1 \mathrm{~min}$ at $56^{\circ} \mathrm{C}$, and $1 \mathrm{~min}$ at $72^{\circ} \mathrm{C}$ ); (iii) $7 \mathrm{~min}$ at $72^{\circ} \mathrm{C}$. Amplified products were separated in $4 \%(\mathrm{w} / \mathrm{v})$ agarose gel, using TBE buffer pH 8.0 ( 0.09 of Tris, $0.09 M$ boric acid, and $2 \mathrm{~m} M$ EDTA), at a constant $90 \mathrm{~V} \mathrm{~cm}^{-1}$. The gels were stained with $10 \mathrm{~mL}$ of ethidium bromide $\left(10 \mathrm{mg} \mathrm{mL}^{-1}\right)$ diluted in $100 \mathrm{~mL}$ of TBE and documented under ultraviolet light (GelDoc 2000, Biorad, Hercules, CA). The primers used were A1-041, A1-558, and LEC-1.

\section{Pollen Viability}

Estimation of pollen viability was made in eight flowers per hybrid combination; anthers were macerated on a slide and pollen staining was done with $2 \%$ acetic carmine. Stained pollen grains were counted to estimate pollen viability.

\section{Amphidiploid Production}

Cuttings approximately $20 \mathrm{~cm}$ long were taken from growing plants, transferred to assay tubes with the growing tips submerged in $0.2 \%$ colchicine, closed with PVC plastic film, and submitted to controlled conditions of fluorescent white light and controlled temperature from 28 to $30^{\circ} \mathrm{C}$ for $8 \mathrm{~h}$. After treatment, cuttings were washed in running water for $20 \mathrm{~min}$, cut at an angle in the oldest internode. Rooting hormone,

Table 1. Species of Arachis, germplasm accessions, country of origin, and Brazilian accession codes used in the crossing experiment.

\begin{tabular}{|c|c|c|c|c|}
\hline Species & Accessions $\dagger$ & $\begin{array}{l}\text { Brazilian accession } \\
\text { code (BRA) }\end{array}$ & Agricultural type & $\begin{array}{c}\text { Country of } \\
\text { origin } \div\end{array}$ \\
\hline A. duranensis Krapov. and W. C. Gregory & VNvEv 14167 & 036200 & - & ARG \\
\hline A. hypogaea L. subsp. fastigiata Waldron var. fastigiata & cv. BR1 & 033383 & valencia & BRA \\
\hline A. hypogaea & cv. IAC-Caiapó & 037371 & virginia & BRA \\
\hline A. hypogaea subsp. fastigiata var. vulgaris C. Harz & cv. Tatuí & 001147 & spanish & BRA \\
\hline A. hypogaea subsp. fastigiata var. hirsuta Köhler & Mf 1538 & 037397 & & ECU \\
\hline A. hypogaea subsp. hypogaea var. hypogaea & Cv IAC-Runner & 037389 & virginia & BRA \\
\hline $\begin{array}{l}\text { A. hypogaea subsp. fastigiata var. aequatoriana } \\
\text { Krapovickas and W.C. Gregory }\end{array}$ & Mf 1678 & 037435 & & ECU \\
\hline A. hypogaea subsp. fastigiata var. fastigiata & cv. IAC-Tatu-ST & 011606 & valencia & BRA \\
\hline $\begin{array}{l}\text { A. hypogaea subsp. fastigiata var. peruviana } \\
\text { Krapov. and W.C. Gregory }\end{array}$ & Mf 1560 & 037401 & & ECU \\
\hline A. hypogaea subsp. hypogaea var. hypogaea & VGaRoSv 12548 & 030708 & virginia & BRA \\
\hline A. hypogaea subsp. hypogaea $\rceil$ & VGaRoSv 12549 & 030716 & & BRA \\
\hline A. ipaënsis Krapov. and W.C. Gregory & KGBPScS 30076\# & $\mathbf{0 3 6 2 3 4}$ & & BOL \\
\hline
\end{tabular}

$\dagger$ Mf, Manfredi Experiment Station, Argentina; B, D.J. Banks; Ev, A. Echeverry; G, W.C. Gregory; Ga, M.L. Galgaro; K, A. Krapovickas; Nv, L. Novara; P,

J.R. Pietrarelli; Ro, D.M.S. Rocha; S, C.E. Simpson; Sc, A. Schinini; V, J.F. M. Valls.

$\uparrow$ ARG, Argentina; BOL, Bolivia; BRA, Brazil; ECU, Ecuador.

$\S$ Pedigree possibly including distinct botanical varieties.

II Very distinct morphological type not yet classified in a formal variety (Freitas and Valls, 2001).

\# KGBPScS 30076 is only accession listed with a PI number assigned (PI 468322). 
Table 2. Morphological structure averages of diploid $(2 x)$ and tetraploid (4x) flowers from the A. ipaënsis and A. duranensis hybrid.

\begin{tabular}{|c|c|c|c|}
\hline \multirow[b]{2}{*}{ Morphological structures } & \multicolumn{3}{|c|}{ KGBPScS $30076 \times$ VNvEv 14167} \\
\hline & $2 x$ & $4 x$ & $P>t$ \\
\hline & \multicolumn{2}{|c|}{$\longrightarrow \mathrm{cm}$} & \\
\hline Standard length & 1.15 & 1.35 & 0.0001 \\
\hline Standard width & 1.31 & 1.59 & $\mathbf{0 . 0 0 3 7}$ \\
\hline Wing length & 0.55 & 0.71 & 0.0003 \\
\hline Wing width & 0.67 & 0.76 & 0.0028 \\
\hline Lower lip length & 0.58 & 0.71 & 0.0028 \\
\hline Upper lip length & 0.54 & 0.59 & 0.1132 \\
\hline Hypanthium length & 4.04 & 5.31 & 0.0103 \\
\hline
\end{tabular}

indole butyric acid, was applied and cuttings were transferred to the screenhouse in plastic cups with vegetable substratum. Cups were conditioned for approximately $20 \mathrm{~d}$ in trays covered with transparent plastic bags to maintain high humidity.

\section{Chromosome Counting of Synthetic Amphidiploid Cuttings}

In January of 2002, the detached leaf protocol of Moraes and Salgado (1984) was adapted for rooting petioles (Fávero et al., 2004). New, totally expanded leaves of the colchicinetreated cuttings were cut and the petioles were treated with indole butyric acid and immediately transferred to cups with vegetable substratum. After, two or more weeks, roots grew and were collected between 1000 and $1400 \mathrm{~h}$.

Chromosome counting was done at the Laboratory of $\mathrm{Cy}$ tology of the Department of Genetics of ESALQ/USP. Methodologies of root tips treatment and cytological preparations were adapted from Aguiar-Perecin and Vosa (1985) and Silvarolla and Aguiar-Perecin (1994).

After observation good preparations were selected and cover slips were removed in $45 \%$ acetic acid and mounted with Canadian balsam. Photomicrographs of the chromosomes were obtained with a Zeiss photomicroscope (Thornwood, NY), using Kodak Technical Pan (ISO 25) film (Rochester, NY).

\section{Morphological Characterization}

Diploid and tetraploid flower structures were measured for evaluation of morphological differences. A digital caliper was used to measure standard length and width, wing length and width, lower and upper lip length, and hypanthium length; $t$ test was used for average comparisons (Table 2).

\section{Crosses between $A$. hypogaea and the Synthetic Amphidiploid}

Some colchicine-treated cuttings of the A. ipaënsis $\times A$. duranensis hybrid were identified to have tetraploid cells. obtained).
Crosses were made between $A$. hypogaea and this material at Embrapa Genetic Resources and Biotechnology in screenhouse conditions from October 2002 to March 2003. Accessions of $A$. hypogaea were used as female parents including germplasm accessions and commercial cultivars, representing distinct agricultural types and all botanical varieties (Table 3 ). Fruits, harvested from March to May, were dried for $1 \mathrm{wk}$, then seeds were removed and placed to germinate.

A second complementary round of crosses, involving additional accessions of $A$. hypogaea was undertaken in 2003 through 2004 , following the same procedures.

Molecular Characterization of Progenies of A. hypogaea and Synthetic Amphidiploid Hybridization

Molecular marker studies were done in the Laboratory of Plant Genetic Characterization of Embrapa Genetic Resources and Biotechnology. In March 2003, leaves were removed from the individual progenies originating from crosses between A. hypogaea and the synthetic amphidiploids for DNA extraction and identification of hybrids using microsatellite markers. Protocol used was adapted from Ferreira and Grattapaglia (1995). Quantification stages, PCR reactions and electrophoresis conditions were the same as before. Primer used was Lec-1. Polyacrylamide gel electrophoresis with silver staining was used for distinction among individuals based on microsatellite marker polymorphism. (Bassam et al., 1991).

\section{RESULTS AND DISCUSSION}

\section{Diploid Crosses and AB Hybrids Obtained}

Seeds of different hybrid progenies were collected between May 2001 and 2004. In the diploid crosses $A$. ipaënsis was used as the female parent because of unsuccessful attempts of introgression by one junior author (C.E. Simpson, unpublished data, 1984-1986) using $A$. duranensis as the female parent. Also, a factor in the decision was that Simpson and Starr (2001) were successful in introgression by using a non-A genome parent as the female.

Microsatellite markers proved to be efficient in the identification of hybrids. All individuals of the progenies could be identified without doubt as to the hybrid or self-pollinated condition.

Twenty-four pollinations were made, resulting in five hybrid plants, with a percentage of success of $20.83 \%$. A diploid cell of the hybrid with a chromosome $\mathrm{A}$ is shown in Fig. 1. From experience of evaluating Arachis chromosomes, it is known that the other small bodies shown in Fig. 1 are chromosome satellites. Stained pollen was $0.98 \%$.

Table 3. Cross combinations between accessions of Arachis hypogaea and synthetic amphidiploid (A. ipaënsis $\times$ A duranensis), number of pollinations, number of hybrid plants obtained, and success percentage (number of pollinations compared with number of hybrids

\begin{tabular}{|c|c|c|c|c|c|c|}
\hline A. hypogaea accessions & & Wild species accessions & No. of pollinations & No. of hybrid plants & Success percentage & No. of $F_{2}$ seeds \\
\hline BR 1 & $x$ & $($ K $30076 \times$ V 14167) & 290 & 34 & 12 & 47 \\
\hline IAC-Caiapó & $x$ & $($ K $30076 \times$ V 14167) & 53 & 16 & 30 & 169 \\
\hline IAC-Runner & $x$ & $($ K $30076 \times$ V 14167) & 62 & 21 & 34 & 210 \\
\hline IAC-Tatu-ST & $x$ & $($ K $30076 \times$ V 14167) & 251 & 13 & 5 & 16 \\
\hline Mf 1560 & $x$ & $($ K $30076 \times$ V 14167) & 21 & 1 & 5 & 3 \\
\hline Mf 1538 & $\hat{x}$ & $($ K $30076 \times$ V 14167) & 68 & 11 & 16 & 107 \\
\hline Mf 1678 & $\hat{x}$ & $($ K $30076 \times$ V 14167) & $\begin{array}{r}00 \\
102\end{array}$ & $3 \dagger$ & - & 31 \\
\hline Tatuí & $x$ & $($ K $30076 \times$ V 14167) & 231 & $7 \dagger$ & - & 16 \\
\hline V 12548 & $x$ & $($ K $30076 \times$ V 14167) & 77 & 4 & 5 & 54 \\
\hline V 12549 & $x$ & $(\mathbf{K ~ 3 0 0 7 6} \times$ V 14167) & 51 & 2 & 4 & 20 \\
\hline
\end{tabular}

$\dagger$ Hybrid plants resulting from precocious germination in hybridization pots. More seed may be available. 


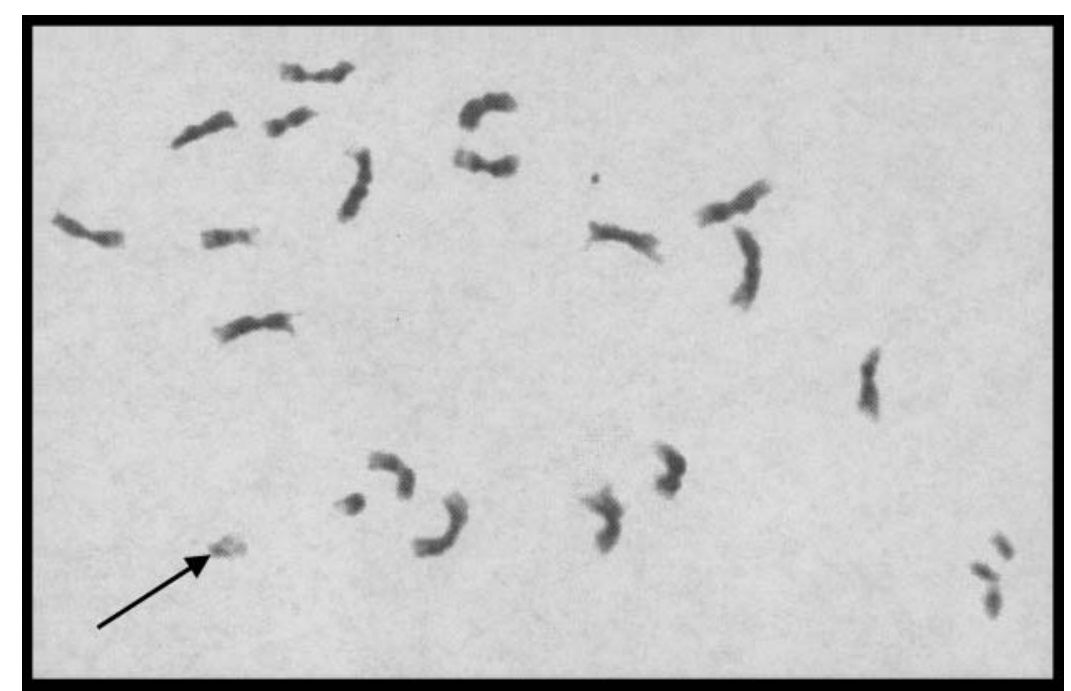

Fig. 1. KGBPScS $30076 \times$ VNvEv 14167 diploid mitotic cell. Black arrow shows the small A chromosome; other small bodies are satellites.

\section{Colchicine Treatment and Tetraploid Plant Obtained}

The hybrid combination KGBPScS $30076 \times$ VNvEv 14167 (A. ipaënsis $\times$ A. duranensis) had cells duplicated after $8 \mathrm{~h}$ of colchicine treatment. As treated tissues are somatic, it was common for chimerical plants to occur. These chimerical plants produced seeds. From these seeds, it was possible to obtain tetraploid plants. Plants originated from these seeds showed flowers with $97.74 \%$ stained pollen.

Measurement data of morphological structures of diploid and tetraploid flowers are shown in Table 2. There were significant differences for all the floral structures measured, except for the upper lip length (Table 2).

\section{Arachis hypogaea and Synthetic Amphidiploid Hybridizations}

Figure 2 shows it is possible to distinguish with microsatellite markers between hybrid individuals and selfpollinated progeny. Polyacrilamide gel was used for progeny distinction of a family of $A$. hypogaea $\mathrm{cv}$. BR$1 \times[$ A. ipaënsis $(\mathrm{KGBPScS} 30076) \times$ A. duranensis $(\mathrm{VNvEv} 14167)]^{4 x}$. Individuals of the progeny indicated by the black arrows were considered as hybrid because they had all bands of both parents. A total of 13 microsatellites were used, but only three were polymorphic in the diploids and just one, Lec-1, was polymorphic in the amphiploids (Fig. 2). It is not clear why all three were not polymorphic.
Table 3 shows crosses made among accessions of $A$. hypogaea and the synthetic amphidiploid, the number of hybrids obtained, and the percentage of success.

An important diagnostic morphological marker is the yellow flower color in the tetraploid hybrids. All $A$. hypogaea accessions used in the work had orange flowers as did A. ipaënsis. Arachis duranensis (VNvEv 14167) with yellow flowers was always used as male parent, and the diploid hybrids consistently showed yellow flowers. Another remarkable morphological characteristic is the significant increase in the number of trichomes on the edges of leaves and on stems of hybrids.

The hybrids obtained from the cross between $A$. hypogaea and the amphidiploid A. ipaënsis $\times$ A. duranensis indicate that these species are closely related to $A$. hypogaea. In evolutionary studies of the cultivated peanut, the possibility of successful hybrids involving $A$. hypogaea, $A$. ipaënsis, and $A$. duranensis was a goal of primary importance to the validation of several studies in molecular, morphological, and cytogenetic characterization previously published (Kochert et al., 1991, 1996; Krapovickas and Gregory, 1994; Fernández and Krapovickas, 1994; Gimenes et al., 2002; Seijo et al., 2004), where different authors agreed that $A$. ipaënsis and $A$. duranensis would be the most probable progenitors of the cultivated peanut.

Singh and Smartt (1998) stated that, since a fertile hybrid had not been obtained from $A$. ipaënsis $\times A$. duranensis and crossed to the cultivated peanut, it was not possible to confirm this hypothesis of the origin of $A$. hypogaea. As the result of our work, hybrids were obtained from crosses between six different botanical

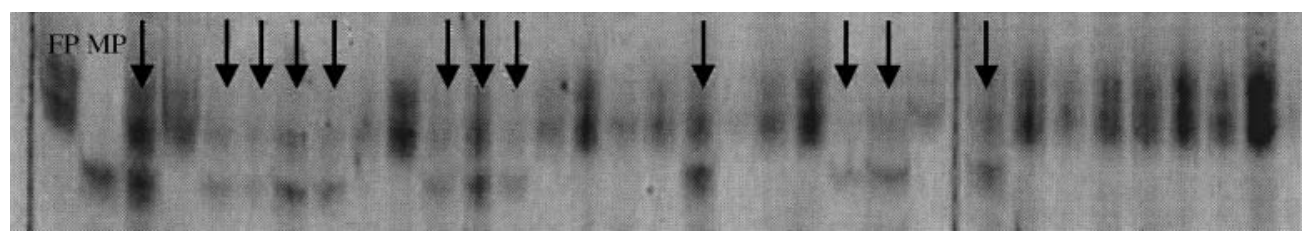

Fig. 2. Polyacrylamide gel with microsatellite (SSR) primer Lec-1. In sequence, family of A. hypogaea cv. BR-1 as female parent (FP), the synthetic amphidiploid A. ipaënsis (KGBPScS 30076) $\times$ A. duranensis (VNvEv 14167) as male parent (MP) and the progeny. Black arrows show hybrid individuals of the progeny. 
varieties of $A$. hypogaea and a fertile synthetic amphidiploid $A$. ipaënsis $\times A$. duranensis. All tetraploid hybrid $F_{1}$ plants produced pegs and seeds, documenting the fertility of the $F_{1}$ interspecific hybrids (Table 3 ).

Further studies of chromosome pairing are underway, but the production of the several $\mathrm{F}_{2}$ progenies at least raises $A$. ipaënsis to the same status attributed by Singh and Smartt (1998) to A. batizocoi, additionally emphasizing the closest association of $A$. ipaënsis to $A$. hypogaea, based on a broad array of investigative approaches.

The fact that fertile hybrids were obtained between the synthetic $A$. ipaënsis $\times A$. duranensis amphidiploid and representatives of both subspecies and even more described varieties of $A$. hypogaea (Krapovickas and Gregory, 1994) than those used by Singh (1988) documents their high potential for the crop improvement, especially when recent studies based on more accurate techniques (Ferguson et al., 2004; Moretzsohn et al., 2004) start to unveil the obvious genetic diversity, previously not well understood, of Arachis germplasm resources.

\section{REFERENCES}

Aguiar-Perecin, M.L.R. de, and C. Vosa. 1985. C-banding in maize. II. Identification of somatic chromosomes. J. Hered. 54:37-42.

Bassam, B.J., G. Caetano-Anolles, and P.M. Gresshoff. 1991. Fast and sensitive silver staining of DNA in polyacrylamide gels. Anal. Biochem. 196:80-83.

Fávero, A.P., S.M. Cuco, M.R.L. de Aguiar-Perecin, J.F.M. Valls, and N.A. Vello. 2004. Rooting in leaf petioles of Arachis for cytological analysis. Cytologia 69:215-219.

Ferguson, M.E., P.J. Bramel, and S. Chandra. 2004. Gene diversity among botanical varieties in peanut (Arachis hypogaea). Crop Sci. 44:1847-1854

Fernández, A., and A. Krapovickas. 1994. Cromosomas y evolución en Arachis (Leguminosae). (In Spanish, with English abstract.) Bonplandia 8:187-220.

Ferreira, M.E., and D. Grattapaglia. 1995. Introdução ao Uso de Marcadores Moleculares em Análise Genética. 2nd ed. EmbrapaCENARGEN, Brasília.

Freitas, F.O., and J.F.M. Valls. 2001. Nota sobre a ocorrência de um tipo distinto de amendoim no parque indígena do Xingú e arredores e suas implicações etnobotânicas. In Simpósio Internacional de Recursos Genéticos para a América Latina e Caribe, Londrina, PR.

Gimenes, M.A., C.R. Lopes, M.L. Galgaro, J.F.M. Valls, and G. Kochert. 2002. RFLP analysis of genetic variation in species of section Arachis, genus Arachis (Leguminosae). Euphytica 123:421-429.

Gregory, W.C., and M.P. Gregory. 1976. Groundnut. p. 151-154. In N.W. Simmonds (ed.) Evolution of crop plants. Longman Group Ltd., London.

Gregory, W.C., A. Krapovickas, and M.P. Gregory. 1980. Structure, variation, evolution and classification in Arachis. p. 469-481. In R.J. Summerfield and A.H. Bunting (ed.) Advances in Legume Science (2). Royal Botanic Gardens, Kew, Surrey, UK.

Hilu, K.W., and H.T. Stalker. 1995. Genetic relationships between peanut and wild species of Arachis sect. Arachis (Fabaceae): Evidence from RAPDs. Plant Syst. Evol. 198:167-178.

Husted, L. 1933. Cytological studies of the peanut Arachis. 1. Chromosome number and morphology. Cytologia 5:109-117.

Husted, L. 1936. Cytological studies of the peanut Arachis. 2. Chromosome number, morphology and behavior, and their application to the problem of the origin of the cultivated forms. Cytologia 7:396-423.

Kochert, G., T. Halward, W.D. Branch, and C.E. Simpson. 1991. RFLP variability in peanut (Arachis hypogaea L.) cultivars and wild species. Theor. Appl. Genet. 81:565-570.

Kochert, G., H.M. Stalker, M. Gimenes, L. Galgaro, C.R. Lopes, and K. Moore. 1996. RFLP and cytogenetic evidence on the origin and evolution of allotetraploid domesticated peanut, Arachis hypogaea (Leguminosae). Am. J. Bot. 83:1282-1291.
Krapovickas, A., and W.C. Gregory. 1994. Taxonomia del género Arachis (Leguminosae). (In Spanish, with English abstract.) Bonplandia 8:1-186.

Krishna, T.G., and R. Mitra. 1988. The probable genome donors to Arachis hypogaea L. based on arachin seed storage protein. Euphytica 37:47-52.

Lavia, G.I. 1998. Karyotypes of Arachis palustris and A. praecox (Section Arachis), two species with basic chromosome number $\mathrm{x}=9$. $\mathrm{Cy}-$ tologia 63:177-181.

Moraes, S. de A., and C.L. Salgado. 1984. Utilização da técnica de folhas destacadas de amendoim (Arachis hypogaea L.) para inoculações com Cercospora arachidicola Hori e Cercospora personata (Bert. \& Curt.) Ell. \& Ev. (In Portuguese, with English abstract.) Summa Phytopath. 8:39-55.

Moretzsohn, M.C., M.S. Hopkins, S.E. Mitchell, S. Kresovich, J.F.M. Valls, and M.E. Ferreira. 2004. Genetic diversity of peanut (Arachis hypogaea L.) and its wild relatives based on the analysis of hypervariable regions of the genome. BMC Plant Biol. $4: 11$.

Murray, M.G., and W.F. Thompson. 1980. Rapid isolation of high molecular-weight plant DNA. Nucleic Acids Res. 8:4321-4325.

Paik-Ro, O.G., R.L. Smith, and D.A. Knauft. 1992. Restriction fragment length polymorphism of six peanut species within the Arachis section. Theor. Appl. Genet. 84:201-208

Peñaloza, A.P.S., and J.F.M. Valls. 1997. Contagem do número cromossômico em acessos de Arachis decora (Leguminosae). In Simpósio Latino-Americano de Recursos Genéticos Vegetais 1:39. IAC, Campinas.

Raina, S.N., and Y. Mukai. 1999a. Detection of a variable number of 18S-5.8S-26S and 5S ribosomal DNA loci by fluorescent in situ hybridization in diploid and tetraploid Arachis species. Genome 42:52-59.

Raina, S.N., and Y. Mukai. 1999b. Genomic in situ hybridization in Arachis (Fabaceae) identifies the diploid wild progenitors of cultivated (A. hypogaea) and related wild (A. monticola) peanut species. Plant Syst. Evol. 214:251-262.

Raina, S.N., V. Rani, T. Kojima, Y. Ogihara, K.P. Singh, and R.M. Devarumath. 2001. RAPD and ISSR fingerprints as useful genetic markers for analysis of genetic diversity, varietal identification, and phylogenetic relationships in peanut (Arachis hypogaea) cultivars and wild species. Genome 44:763-772.

Seijo, J.G., G.I. Lavia, A. Fernández, A. Krapovickas, D. Ducasse, and E.A. Moscone. 2004. Physical mapping of the 5S and 18S-25S rRNA genes by fish as evidence that Arachis duranensis and $A$. ipaënsis are the wild diploid progenitors of A. hypogaea. Am. J. Bot. 91:1294-1303.

Silvarolla, M.B., and M.L.R. de Aguiar-Perecin. 1994. Evaluation of chromosome number stability in two sugarcane varieties. Braz. J. Genet. 17:237-242

Simpson, C.E., and J.L. Starr. 2001. Registration of 'COAN' peanut. Crop Sci. 41:918.

Simpson, C.E., J.F.M. Valls, and A. Krapovickas. 2001. History of Arachis including evidence of $A$. hypogaea L. progenitors. Peanut Sci. 28:78-80.

Singh, A.K. 1986. Utilization of wild relatives in the genetic improvement of Arachis hypogaea L. 8. Synthetic amphidiploids and their importance in interspecific breeding. Theor. Appl. Genet. 72:433-439.

Singh, A.K. 1988. Putative genome donors of Arachis hypogaea (Fabaceae), evidence from crosses with synthetic amphidiploid. Plant Syst. Evol. 160:143-151.

Singh, A.K., and J. Smartt. 1998. The genome donors of the groundnut/ peanut (Arachis hypogaea L.) revisited. Genet. Res. Crop Evol. 45:113-118.

Singh, K.P., A. Singh, S.N. Raina, A.K. Singh, and Y. Ogihara. 2002. Ribosomal DNA repeat unit polymorphism and heritability in peanut (Arachis hypogaea L.) accessions and related wild species. Euphytica 123:211-220.

Smartt, J., W.C. Gregory, and M.P. Gregory. 1978. The genomes of Arachis hypogaea. 1. Cytogenetic studies of putative genome donors. Euphytica 27:665-675.

Stalker, H.T. 1989. Utilizing wild Species for crop improvement p. 139-154. In H.T. Stalker and C. Chapman (ed.) IBPGR Training Courses: Lecture Series, 2. Scientific Management of Germplasm: 
Characterization, Evaluation and Enhancement. Int. Board for Plant Genet. Resour., Rome.

Stalker, H.T. 1991. A new species in section Arachis of peanuts with a D genome. Am. J. Bot. 78:630-637.

Stalker, H.T., and R.D. Dalmacio. 1986. Karyotype analysis and relationships among varieties of Arachis hypogaea L. Cytologia 51: 617-629.

Stalker, H.T., J.S. Dhesi, D.C. Parry, and J.H. Hahn. 1991. Cytological and interfertility relationships of Arachis Section Arachis. Am. J. Bot. 78:238-246.

Valls, J.F.M., and C.E. Simpson. 1994. Taxonomy, natural distribution, and attributes of Arachis. p. 1-18. In P.C. Kerridge and B. Hardy (ed.) Biology and Agronomy of Forage Arachis. Centro Intern. de Agri. Trop., Cali.

Valls, J.F.M., and C.E. Simpson. 2005. New species of Arachis from Brazil, Paraguay, and Bolivia. Bonplandia 14(1\&2):35-64. 